\title{
PRODUCTIVITY IMPROVEMENT OF \\ CANTALOUPE UNDER LOW TEMPERATURE CONDITIONS ON SIWA OASIS
}

\author{
El-Sagan, Mohamed A.M. \\ Vegatable Unit, Department of Plant Production, Desert Research Center, \\ El-Matareya, Cairo, Egypt \\ E-mail:drm_elsagan@yahoo.com
}

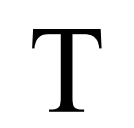

his field experiment was performed at the Experimental Farm of the Desert Research Center, Siwa Oasis, Marsa Matroh Governorate, during the two consecutive seasons of 2015/2016 and 2016/2017. The experiments were conducted to study the effect of soil mulch and two commercial anti-transpiration products i.e., anticool ( 2 and $4 \mathrm{ml} / \mathrm{L})$ and green miracle (2 and 4 $\mathrm{ml} / \mathrm{L}$ ) beside control treatment as foliar application on growth, yield and chemical composition of cantaloupe plants cv. Regal grown under sandy soil conditions. Results revealed that soil mulch treatment significantly increased all most growth characters; yield and its components when compared with control treatment in both seasons. Foliar spray by green miracle at the rate of $4 \mathrm{ml} / \mathrm{L}$ showed a significant increase in plant height and weight; no. of branches/plant; leaf area; SPAD value; fruit weight and diameter; fruit moister (\%); plant yield and total yield/feddan in both seasons. While, anticool rate of $4 \mathrm{ml} / \mathrm{L}$ showed significant increase in shoot dry matter (\%); no. of leaves/plant; fruit T.S.S. and firmness and early yield in both seasons. Correlation and regression of some parameters indicated that for each one gram increase of plant weight was corresponding to the increase in fruit weight by 0.93 and $0.68 \mathrm{~g}$ and for each increase of one gram of fruit weight, total yield correspondingly increased by 0.031 and 0.025 ton/feddan, during the first and second seasons, respectively.

Keywords: cantaloupe, mulch, antytranspiration, growth, fruit quality, yield

Cantaloupe fruit (Cucumis melo L.) is one of the most popular fruity vegetables grown in Egypt; it belongs to Cucurbitaceae crop and the fruits contain high amounts of phenolic; flavonoids; vitamins; carbohydrates and minerals with very few amounts of fat and calories (Adeyeye et al., 2017). It is important from an economic point of view that especially the area of its cultivation is increasing gradually in the newly reclaimed lands. In Egypt, total cultivated area in 2015 was 36657 feddan, and the total production was 280131 ton. It is one of the most important exported crops (FAO STAT, 2018). 
The material spread on the surface of soil to protect it from solar radiation or evaporation is called mulch. The different types of materials as wheat straw, rice straw, plastic film, grass, sand etc. are used as mulches. The mulch has moderate soil temperature and increase water infiltration during intensive rain (Khurshid et al., 2006). Plastic-culture, including row covers, plastic mulch has been an important tool for crop diversification and season extension as it enables farmer in to create microclimates better suited to heat-loving crops such as muskmelon (Cucumis melo) (Wells and Loy, 1993 and Lamont, 1996). Colors of plastic mulch used in commercial vegetable production: i.e., black, transparent and white (or white-on black) reflective mulches. The black mulch is being the dominant color used for vegetables (Gordon et al., 2010 and Hochmuth et al., 2012).

Muskmelons are typically grown on raised beds covered with black plastic mulch, which has been shown to increase earliness by up to 7 days and to double yields over planting in bare soil. However, mulch does little to enhance air temperature (Loy and Wells, 1975). Also, it has been proved that plastic mulch treatment resulted in higher plant height, leaf area, fruit number, early fruit yield, total yield of muskmelon and high water use efficiency than non-mulch treatment (Alenazi et al., 2015). From the side of climatology, mulching directly influence the microclimate around the plant by modifying the radiation resources of the surface and declining the soil water loss (Moursy et al., 2015). Generally, many studies proved that benefits of mulch in the production of vegetable crops are well established and has many advantages such as reducing nutrient leaching, decreasing soil evaporation, increasing soil moisture conservation and controlling weeds. In turn, crop soil coverage leads to earlier harvests, uniform and high yield as a result of the increase in soil temperature (Lamont, 2005; Ban et al., 2009; De Pascale et al., 2011 and Hochmuth et al., 2012).

Plants are continuously exposed to various environmental stresses during their growth and development, which cause a considerable yield loss. Low-temperature stress can induce the generation of reactive oxygen species (ROS) and the accumulation of malondialdehyde and proline in plants, damage the ultrastructure of phloem and photosynthetic apparatus and reduce the photosynthetic efficiency (Zhang et al., 2014 and Yang et al., 2016).

A number of commercially available chemical spray-on products are currently marketed to provide some abiotic stresses protection for various crops. Such products include anti-transpirants, biochemical compounds and plant growth regulators. Anti-transpirants based on their mechanism of action, were divided into three categories, namely; film forming types (which coat leaf surface with films that are impervious to water vapor), reflecting materials (which reflect back a portion of the incident radiation falling on the upper surface of the leaves) and stomatal closing types (which affect the metabolic processes in leaf tissues). Also, in plant, $5 \%$ of water 
uptake is used for its growth and development, while the remaining $95 \%$ is lost for transpiration (Prakash and Ramachandran, 2000).

Those antitranspirants are beneficial in increasing plant water potential and stimulating cell division and growth characters could result in enhancing growth of fruits (Wand et al., 2006). Moreover, studies conducted on tomato and potato have shown that foliar applications of kaolin particle films reduce plant stress, which is important for optimum plant growth, yield and quality (Anwar, 2005; Pace et al., 2007 and Cantore et al., 2009). Also, many studies showed that melatonin can act directly as an effective antioxidant, decreasing concentrations of ROS and reactive nitrogen species (RNS), can enhance plant resistance by reducing environmental stress and biological stress damage (Wang et al., 2013).

\section{MATERIALS AND METHODS}

The field experiment was conducted on cantaloupe plants belonging to Cucurbitaceae family, at Siwa Research Station of the Desert Research Center, Marsa Matroh Governorate, during the two consecutive winter seasons of 2015/2016 and 2016/2017. The experiments were conducted to study the effect of soil mulch and two commercial anti-transpiration products i.e., anticool and green miracle as foliar application on growth, yield and chemical composition of cantaloupe plants cv. Regal grown in sandy soil conditions.

Ten treatments were used, which were the combination of two soil cover i.e., black plastic sheet (100 micron) and without cover as control treatment and five levels of foliar application i.e., anticool at the rate of 2 and $4 \mathrm{ml} / \mathrm{L}$, green miracle at the rate of 2 and $4 \mathrm{ml} / \mathrm{L}$ and control treatment (spray by tap water). Anticool consists of $12.5 \% \mathrm{~N}, 2.5 \% \mathrm{P}, 8.5 \% \mathrm{~K}, 0.5 \%$ $\mathrm{Fe}, 2.5 \% \mathrm{Ca}$ and $5.5 \% \mathrm{Mg}$ produced by Cera Chima Company. Also, Green miracle consists of $80 \%$ fatty alcohol and diluents, $10 \%$ neutralizer, $5 \%$ emulsifier, 5\% stabilizer produced by Stanes Company India, Import by Gahara Company. The physical and chemical soil characteristics of the studied site were determined according to Page et al. (1982) and Klute (1986), respectively, as recorded in table (1). The chemical analysis of irrigation water was carried out using the standard method of Page et al. (1982) and presented in table (2). 
Table (1). Some physical and chemical properties of the experimental soil site.

\begin{tabular}{|c|c|c|c|c|c|c|c|c|c|c|}
\hline \multirow{2}{*}{$\begin{array}{c}\text { Soil } \\
\text { depth } \\
\text { (cm) }\end{array}$} & \multirow{2}{*}{$\begin{array}{c}\text { Texture } \\
\text { class }\end{array}$} & \multicolumn{3}{|c|}{ Soluble anions (me/l) } & \multirow{2}{*}{$\begin{array}{c}\text { pH } \\
\text { of soil } \\
\text { paste }\end{array}$} & \multirow{2}{*}{$\begin{array}{c}\text { E.C } \\
\left(\mathrm{dSm}^{-1}\right)\end{array}$} & \multicolumn{4}{|c|}{ Soluble cations (me/l) } \\
\hline & & $\mathrm{HCO}_{3}^{-}$ & $\mathrm{SO}_{4}{ }^{=}$ & $\mathrm{Cl}^{-}$ & & & $\mathrm{Ca}^{++}$ & $\mathbf{M g}^{++}$ & $\mathbf{N a}^{+}$ & $\mathbf{K}^{+}$ \\
\hline $0-25$ & $\begin{array}{l}\text { Sandy } \\
\text { loam }\end{array}$ & 0.75 & 0.85 & 4.25 & 6.7 & 0.58 & 1.15 & 0.45 & 3.92 & 0.33 \\
\hline
\end{tabular}

pH: Acidity, E.C.: Electrical conductivity, me/l: milli equivalent per liter

Table (2). Chemical analysis of the irrigation water.

\begin{tabular}{|c|c|c|c|c|c|c|c|c|c|}
\hline \multirow{2}{*}{ Samples } & \multirow{2}{*}{$\mathbf{p H}$} & \multirow{2}{*}{$\begin{array}{c}\text { E.C. } \\
\left(\mathbf{d S m}^{-1}\right)\end{array}$} & \multicolumn{2}{|c|}{ Soluble cations (me/l) } & \multicolumn{3}{|c|}{$\begin{array}{c}\text { Soluble anions } \\
(\mathbf{m e} / \mathbf{l})\end{array}$} \\
\cline { 4 - 10 } & & $\mathbf{C a}^{++}$ & $\mathbf{M g}^{++}$ & $\mathbf{N a}^{+}$ & $\mathbf{K}^{+}$ & $\mathbf{H C O}_{3}^{-}$ & $\mathbf{S O}_{4}{ }^{+}$ & $\mathbf{C l}^{-}$ \\
\hline \multirow{2}{*}{$1^{\text {st. }}$ Season } & 7.1 & 5.54 & 10.1 & 13.32 & 39.4 & 1.17 & 9.35 & 15.1 & 39.5 \\
\hline
\end{tabular}

pH: Acidity, E.C.: Electrical conductivity, $\mathrm{dSm}^{-1}$ : decimenz per meter

\section{Land Preparation and Transplant}

Agricultural practices were conducted as Egyptian Ministry of Agricultural recommendation i.e., organic manure was added at the rate of $30 \mathrm{~m}^{3} /$ feddan; $75 \mathrm{~kg}$ of $\mathrm{P}_{2} \mathrm{O}_{5}$, magnesium sulphate at the rate of 50 $\mathrm{kg} /$ feddan, and agricultural sulphate at the rate of $50 \mathrm{~kg} / \mathrm{feddan}$, were added during land preparation. Nitrogen fertilizer $(\mathrm{N})$ and $\left(\mathrm{K}_{2} \mathrm{O}\right)$ at the rate of 90 and $60 \mathrm{~kg} /$ feddan, respectively. Nitrogen and potassium quantities were divided and applied with irrigation during growing season started after 30 days from transplanting. Cantaloupe seedlings were planted in first week of November through the two growing seasons, respectively. Transplanting were planted $50 \mathrm{~cm}$ apart on one side of the ridge and irrigated with drip irrigation system. The ridges were $150 \mathrm{~cm}$ width among drip irrigation lines and $30 \mathrm{~m}$ long. Ridge was covered by a black plastic sheet (100 micron), holes were opened at $50 \mathrm{~cm}$ for planting before transplanting. After 20, 40 and 60 days from transplanting, all foliar spray treatments were applied.

\section{Parameters of Vegetative Growth}

After 90 days from transplanting, three plants of each experimental plot were randomly taken for recording vegetative growth characteristics i.e., (plant height and weight, number of stems/plant and percentage of dry weight of the aerial vegetative parts and root). Leaf area was measured using an automatic leaf area meter AREAMETR (cl-202). Total chlorophyll in plant leaves were measured as SPAD units using Minolta chlorophyll meter (model SPAD 502). Chlorophyll measurements were made using the 
recently third fully expanded leaf and 10 readings were averaged per experimental unit according to A.O.A.C. (1990).

\section{Yield and its Components}

\subsection{Early yield}

Fruit of first harvest (representing fruits with acceptable color and size) from each treatment were weighted calculated the early yield $\left(\mathrm{kg} / \mathrm{m}^{2}\right)$. The first harvest date at 90 days from transplanting in both seasons.

\subsection{Total yield}

All harvests time from each treatment were weighted and calculated from each plot to calculated average fruit number/plant and total yield (kg/plot).

\subsection{Fruit parameters and quality}

At fruit ripening stage a sample of three cantaloupe plants randomly taken from each experimental unit to determine fruit characteristics, i.e., average fruit diameter $(\mathrm{cm}$.); fruit weight $(\mathrm{g})$; fruit moister percentage; fruit hardness $\left(\mathrm{Ib} / \mathrm{inch}^{2}\right)$ and total soluble solids (TSS) of fruit were determined using a JK-SR-113ATC digital Refractometer (Shanghi Co. Ld., China) at $20^{\circ} \mathrm{C}$ (A.O.A.C., 1975). The samples of cantaloupe fruit were taken and dried in oven at $70^{\circ} \mathrm{C}$ until stable weight, then ground to fine particles and used to determine chemical contents such as minerals content $(\mathrm{Ca})$ were measured using Flame Photometer method as described by Brown and Lilliland (1964). Total carbohydrates were determined according to A.O.A.C. (1990).

\section{Experimental Design and Statistical Analysis}

The experimental treatments were arranged in split plot design with three replicates, the main plots were assigned for soil cover, whereas, foliar spray rates were randomly arranged in the sub plots. Statistical analyses of obtained data were analyzed according to Thomas and Hills (1975).

\section{RESULTS AND DISCUSSION}

\section{Plant Growth Parameters}

Growth parameters, i.e., plant height and weight, shoot and root dry matter percent, number of leaves and branches/plant, leaves area $\left(\mathrm{cm}^{2}\right)$ and SPAD value were presented in tables (3 and 4$)$. The obtained results indicated significant positive effect of both soil mulch and foliar spray on all investigated growth parameters. From the data, the following could be remarked:

- The highest and significant values in plant height and weight, number of leaves and branches/plant, leaves area $\left(\mathrm{cm}^{2}\right)$ and SPAD value were 


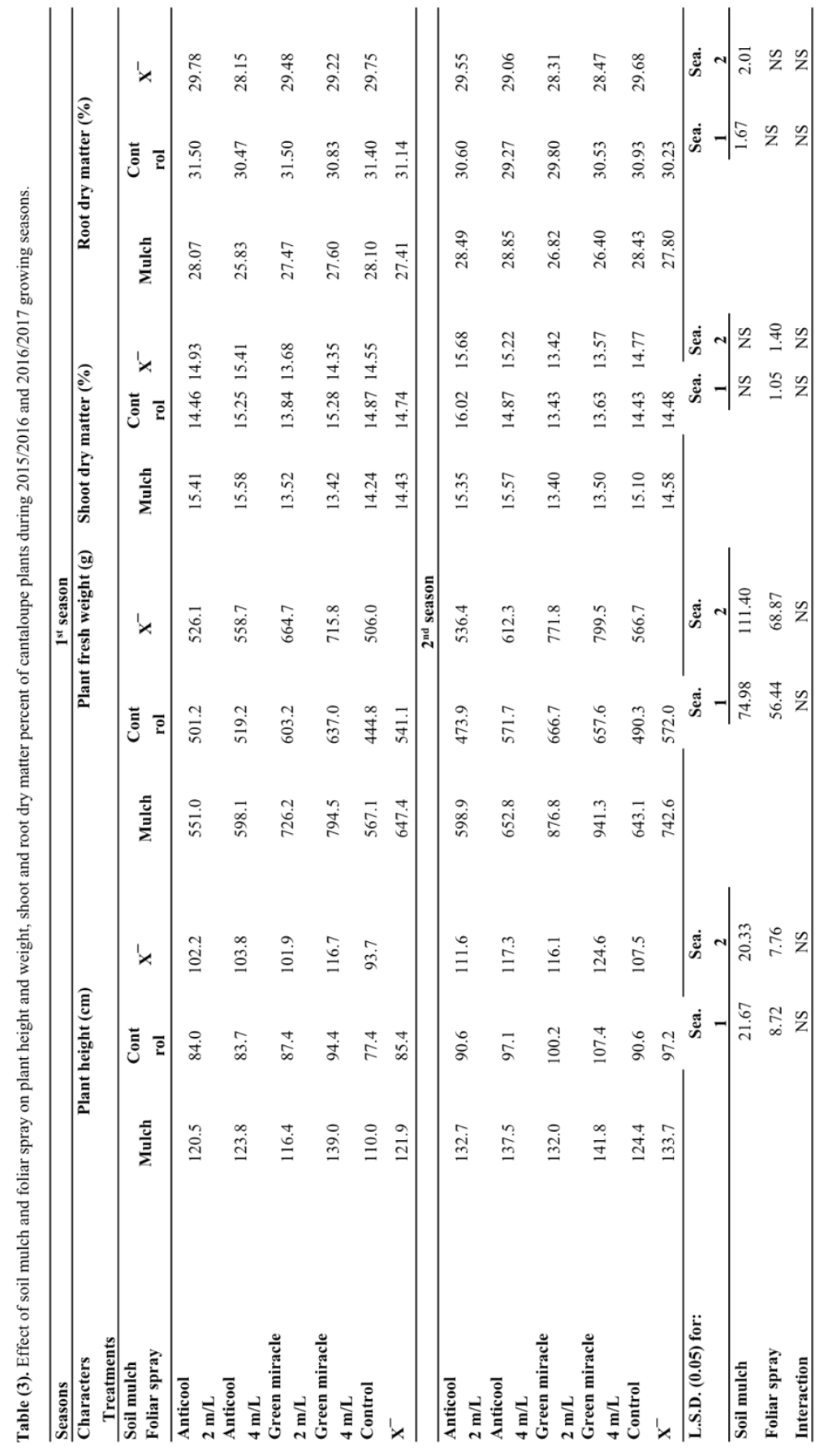

Egyptian J. Desert Res., 70, No. 2, 121-136 (2020) 


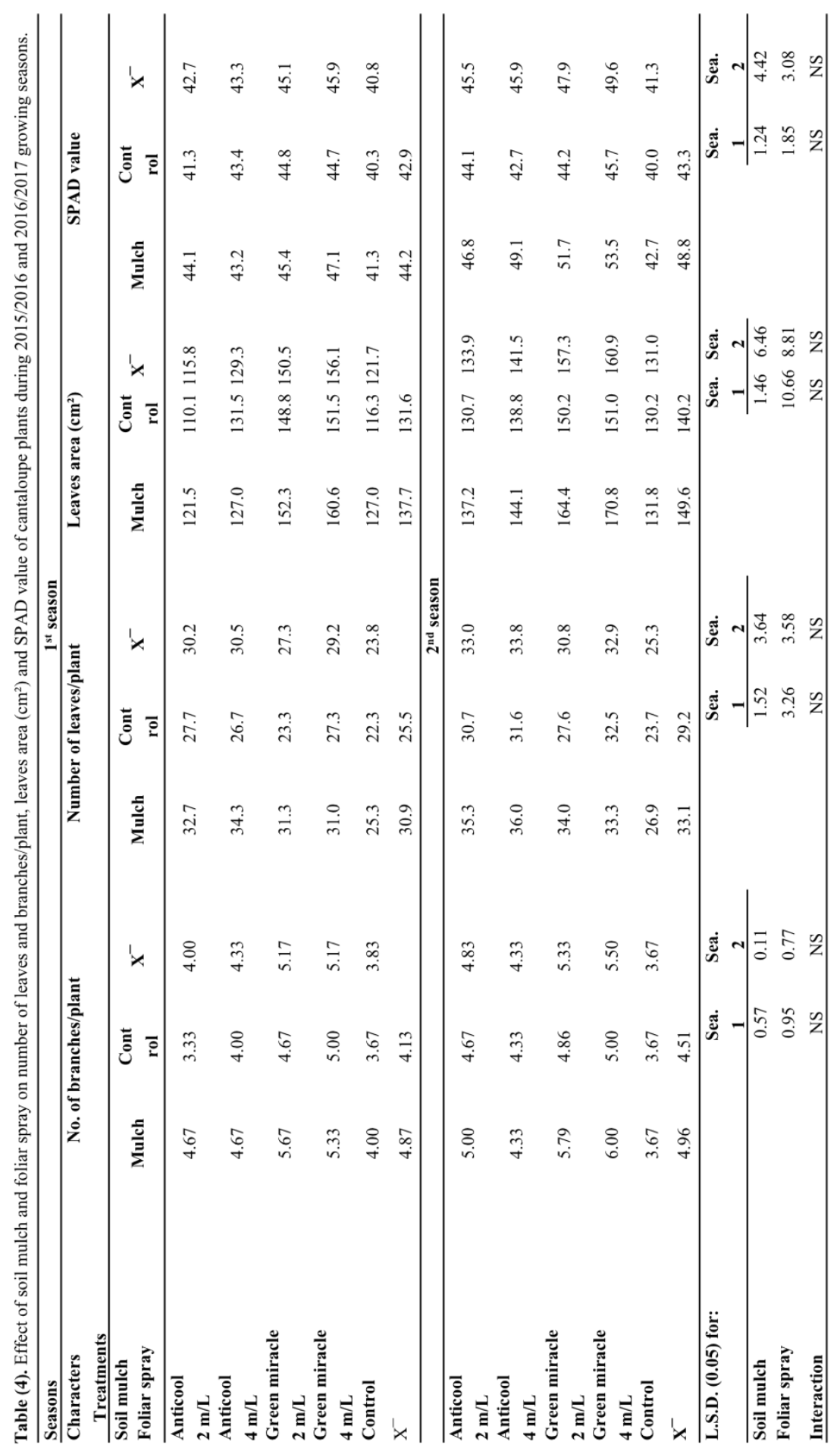

Egyptian J. Desert Res., 70, No. 2, 121-136 (2020) 
recorded with mulch treatment in both seasons. While, the highest values of root dry matter percentage were recorded without mulch treatment and no significant difference between both treatments in shoot dry matter percentage was observed in both seasons. The results recorded in tables ( 3 and 4) are in the same line with those obtained by Lamont (2005), Ban et al. (2009), De Pascale et al. (2011) and Hochmuth et al. (2012), who proved that benefits of mulch in the production of vegetable crops are well established and has many advantages, such as reducing nutrient leaching, decreasing soil evaporation, increasing soil moisture conservation and controlling weeds. The enhancing in growth parameters may be due to the increase in soil temperature that in turn increase root activity and nutrients uptake, which can be reflected on plant growth and development, that is agreement with Alenazi et al. (2015), when reported that mulch treatment has higher plant height, leaf area, and growth parameters of muskmelon and high (WUE) than non-mulch treatment.

- Foliar spray by green miracle at the rate of $4 \mathrm{ml} / \mathrm{L}$, followed by $2 \mathrm{ml} / \mathrm{L}$ showed significant increase in plant height and weight, number of branches/plant, leaf area and SPAD value in both seasons. Concerning the anticool, rate of $4 \mathrm{ml} / \mathrm{L}$, followed by $2 \mathrm{ml} / \mathrm{L}$ showed significant increase in shoot dry matter (\%) and no. of leaves/plant in the both seasons. These results may be due to benefits of these antitranspirants on increasing plant water potential and stimulating cell division and reducing plant stress, which is important for optimum plant growth (Anwar, 2005, Wand et al., 2006; Pace et al., 2007 and Cantore et al., 2009).

\section{Fruit Quality, Yield and its Components}

Results concerned with the number of fruits/plant; fruit weight and diameter; fruit moisture percentage; fruit T.S.S and firmness; fruit content of total carbohydrates and $\mathrm{Ca}(\%)$. Total plant yield, also early and total yield for all treatments were presented in tables $(5,6$ and 7$)$ the following data could be concluded:

- It was clear that soil mulch treatment significantly increased in fruit and yield and its components parameters when compared with control treatment (without mulching) in both seasons. While, without mulch treatment had the highest values in fruit T.S.S and firmness in both seasons. The enhancing in fruit quality and yield and its components may be due to the role of soil mulch in improving soil moisture conservation, increasing soil temperature, reducing nutrient leaching and decreasing soil evaporation, which reflect on increasing root capability to uptake water and elements, which increase growth and yield of plant (Well and Loy, 1993; Lamont, 1996 and 2005; Ban et al., 2009; De Pascale et al., 2011; Hochmuth et al., 2012 and Moursy et al., 2015). 
PRODUCTIVITY IMPROVEMENT OF CANTALOUPE

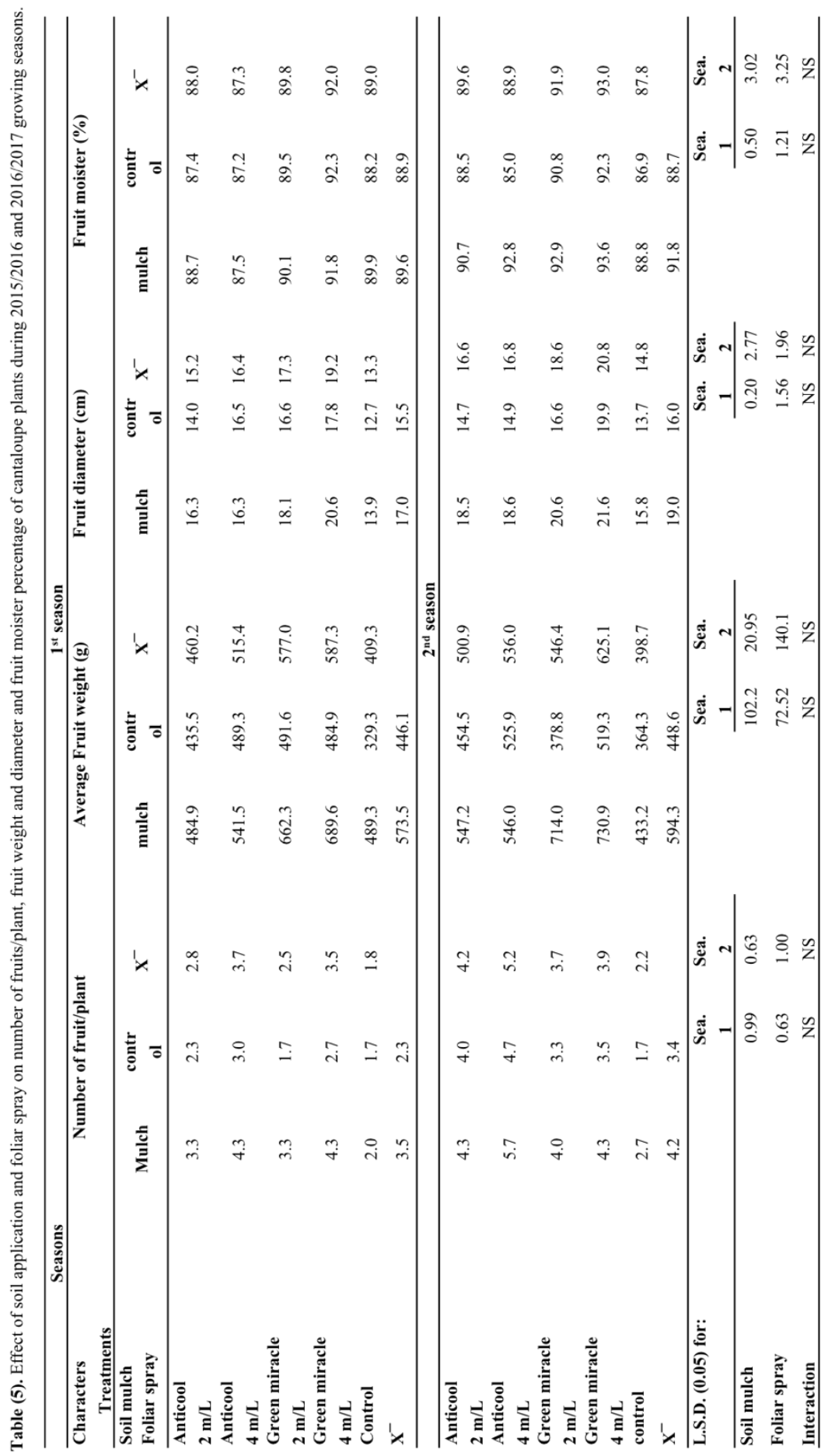

Egyptian J. Desert Res., 70, No. 2, 121-136 (2020) 
El-Sagan, M.A.M.

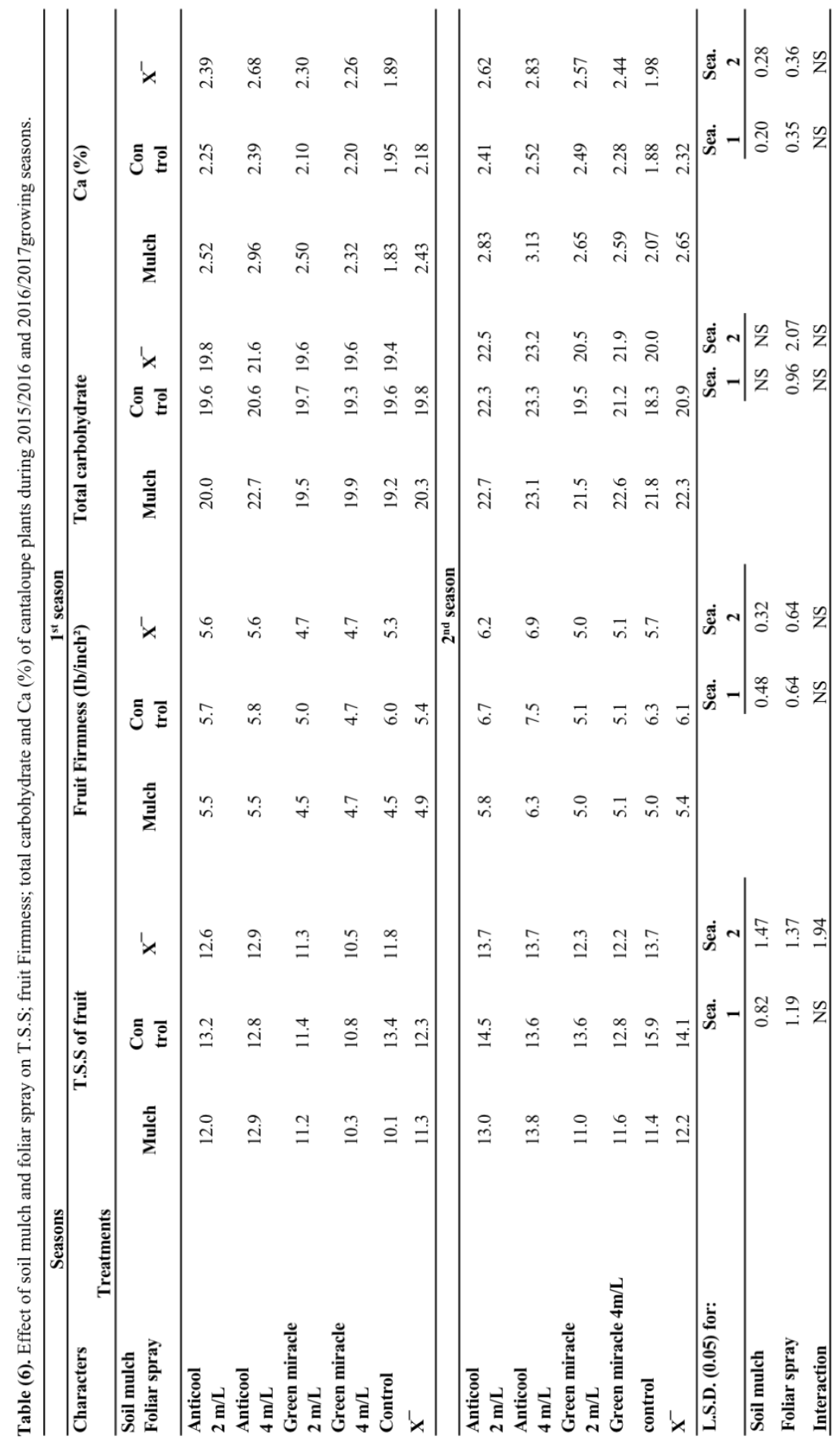

Egyptian J. Desert Res., 70, No. 2, 121-136 (2020) 
Table (7). Effect of soil mulch and foliar spray on plant yield, early yield (\%) and total of cucumber fruit during 2015/2016 and 2016/2017 growing seasons.

\begin{tabular}{|c|c|c|c|c|c|c|c|c|c|}
\hline \multirow{2}{*}{$\begin{array}{l}\text { Seasons } \\
\begin{array}{c}\text { Characters } \\
\text { Treatments }\end{array} \\
\end{array}$} & \multicolumn{9}{|c|}{$1^{\text {st }}$ season } \\
\hline & \multicolumn{3}{|c|}{ Plant yield (kg) } & \multicolumn{3}{|c|}{ Early yield (\%) } & \multicolumn{3}{|c|}{ Total yield (ton/feddan) } \\
\hline $\begin{array}{l}\text { Soil mulch } \\
\text { Foliar spray }\end{array}$ & Mulch & Control & $\mathbf{X}^{-}$ & Mulch & Control & $\mathbf{X}^{-}$ & Mulch & Control & $\mathbf{X}^{-}$ \\
\hline $\begin{array}{l}\text { Anticool } \\
2 \mathrm{~m} / \mathrm{L}\end{array}$ & 1.60 & 1.01 & 1.30 & 30.7 & 26.1 & 28.4 & 8.79 & 6.18 & 7.48 \\
\hline $\begin{array}{l}\text { Anticool } \\
4 \mathrm{~m} / \mathrm{L}\end{array}$ & 2.33 & 1.47 & 1.90 & 33.1 & 27.8 & 30.5 & 11.75 & 8.07 & 9.91 \\
\hline $\begin{array}{l}\text { Green miracle } \\
2 \mathrm{~m} / \mathrm{L}\end{array}$ & 2.20 & 0.80 & 1.50 & 24.9 & 24.4 & 24.7 & 12.08 & 5.34 & 8.71 \\
\hline $\begin{array}{l}\text { Green miracle } \\
4 \mathrm{~m} / \mathrm{L}\end{array}$ & 2.97 & 1.30 & 2.13 & 29.4 & 24.1 & 26.7 & 16.32 & 8.23 & 12.27 \\
\hline Control & 0.98 & 0.54 & 0.76 & 21.6 & 18.1 & 19.8 & 5.38 & 4.42 & 4.90 \\
\hline \multirow[t]{2}{*}{$\mathbf{X}^{-}$} & 2.01 & 1.02 & & 27.9 & 24.1 & & 10.86 & 6.45 & \\
\hline & \multicolumn{9}{|c|}{$2^{\text {nd }}$ season } \\
\hline $\begin{array}{l}\text { Anticool } \\
2 \mathrm{~m} / \mathrm{L}\end{array}$ & 1.74 & 1.35 & 1.55 & 33.4 & 29.3 & 31.3 & 9.62 & 7.33 & 8.47 \\
\hline $\begin{array}{l}\text { Anticool } \\
4 \mathrm{~m} / \mathrm{L}\end{array}$ & 2.59 & 1.74 & 2.17 & 35.8 & 29.2 & 32.5 & 11.53 & 8.86 & 10.20 \\
\hline $\begin{array}{l}\text { Green miracle } \\
2 \mathrm{~m} / \mathrm{L}\end{array}$ & 2.43 & 1.05 & 1.74 & 28.3 & 26.7 & 27.5 & 13.27 & 7.42 & 10.35 \\
\hline $\begin{array}{l}\text { Green miracle } \\
4 \mathrm{~m} / \mathrm{L}\end{array}$ & 3.31 & 1.54 & 2.43 & 31.5 & 28.6 & 30.0 & 15.79 & 9.20 & 12.50 \\
\hline Control & 1.22 & 0.64 & 0.93 & 23.4 & 21.5 & 22.4 & 6.11 & 5.26 & 5.68 \\
\hline $\mathbf{X}^{-}$ & 2.26 & 1.27 & & 30.5 & 27.1 & & 11.27 & 7.61 & \\
\hline L.S.D. (0.05) for: & & $\begin{array}{c}\text { Sea. } \\
1\end{array}$ & $\begin{array}{l}\text { Sea. } \\
2\end{array}$ & & & $\begin{array}{c}\text { Sea. } \\
2\end{array}$ & & & $\begin{array}{l}\text { Sea. } \\
2\end{array}$ \\
\hline Soil mulch & & 0.53 & 0.84 & & & 3.40 & & & 2.00 \\
\hline Foliar spray & & 0.27 & 0.30 & & & 2.93 & & & 1.30 \\
\hline Interaction & & 0.39 & 0.43 & & & NS & & & 1.84 \\
\hline
\end{tabular}


- Green miracle at the rate of $4 \mathrm{ml} / \mathrm{L}$ followed by $2 \mathrm{ml} / \mathrm{L}$ showed significant increase in fruit weight and diameter; fruit moister percentage in both seasons, also Green miracle at the rate of $4 \mathrm{ml} / \mathrm{L}$, followed by anticool at rate of $4 \mathrm{ml} / \mathrm{L}$ showed significant increase in plant yield in both seasons. Green miracle at the rate of $4 \mathrm{ml} / \mathrm{L}$ showed the highest significant increase in total yield in both seasons. Also, foliar spray by anticool at rate of $4 \mathrm{ml} / \mathrm{L}$ followed by anticool at rate of $2 \mathrm{ml} / \mathrm{L}$ recorded the highest values in fruit T.S.S, firmness and early yield in both seasons and number of fruits/plant in the second season only. Some of the essential elements are considered as immobile elements and the plants need a constant supply of those elements for vigorous leaf and root development. Such elements connected with water movement in plant, this movement decreased with decreased temperature, so as they were mulched, before that, anticool consisted of $12.5 \% \mathrm{~N}, 2.5 \% \mathrm{P}, 8.5 \% \mathrm{~K}$, $0.5 \% \mathrm{Fe}, 2.5 \% \mathrm{Ca}$ and $5.5 \% \mathrm{Mg}$. Also, Green miracle consisted of $80 \%$ fatty alcohol and diluents, $10 \%$ neutralizer, $5 \%$ emulsifier, $5 \%$ stabilizer, so foliar spray by such material could be faster supplier of elements and increase water potential in plant cells, which enhanced growth and development in plant. These results are in the same line with those reported by Prakash and Ramachandran (2000), Anwar (2005), Pace et al. (2007), Cantore et al. (2009) and Wang et al. (2013).

- The interaction between the study treatments showed that the combination between soil mulch and foliar spray by green miracle at the rate of $4 \mathrm{ml} / \mathrm{L}$ showed the highest significant increase in plant and total yield in both seasons.

\section{Correlation and Regression}

It is great important to know in how far the different investigated parameters are correlated of each other. It can be seen from fig. (1) that fruit weight was significantly correlated with plant weight. Correlation coefficients (r) were 0.940 and 0.824 in the first and second seasons, respectively. Corresponding coefficients of determination $\left(\mathrm{r}^{2}\right)$ were 0.884 and 0.679 , indicating that 88.4 to $67.9 \%$ of the variation in fruit weight was related to the plant weight. On the other hand, the regression coefficients (b) were 0.933 and 0.686 in the first and second seasons, respectively. This indicates that each one-gram increase in plant weight is corresponding to increase by 0.93 and $0.68 \mathrm{~g}$. Similarly, highly significant positive correlations existed between total yield (ton/feddan) and fruit weight (Fig. 1). A linear regression showed that for each increase of one gram of fruit weight, total yield correspondingly increased by 0.031 and 0.025 ton/feddan, during the first and second seasons, respectively.

Egyptian J. Desert Res., 70, No. 2, 121-136 (2020) 


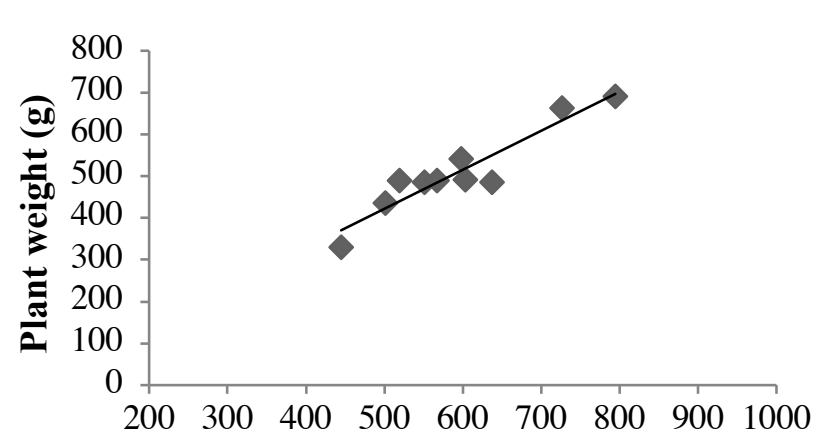

Fruit weight (g)

Regression of Fruit weight on plant weight $\hat{Y}=-44.78+0.933 X, r=0.940, r^{2}=0.884, b=0.933$.

First season

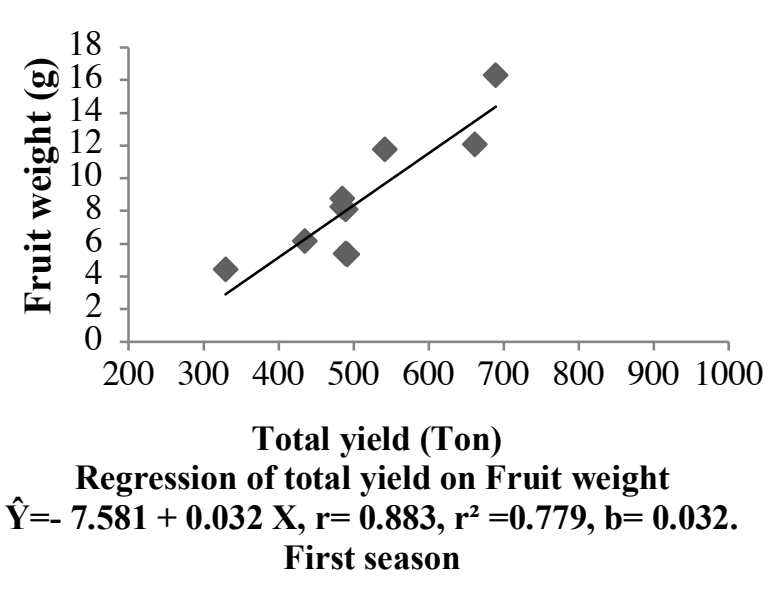

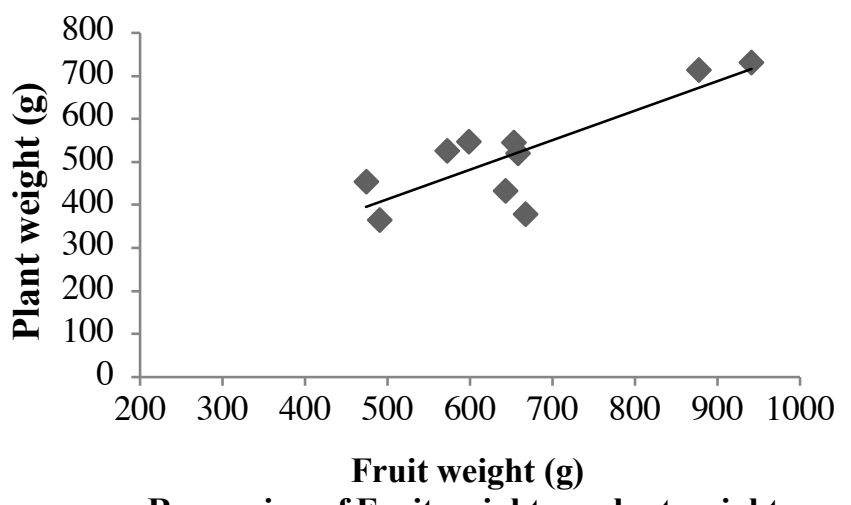

Regression of Fruit weight on plant weight $\hat{\mathbf{Y}}=\mathbf{7 0 . 4 5}+\mathbf{0 . 6 8 6} \mathrm{X}, \mathrm{r}=\mathbf{0 . 8 4 2}, \mathrm{r}^{2}=\mathbf{0 . 6 7 9}, \mathrm{b}=\mathbf{0 . 6 8 6}$. Second season

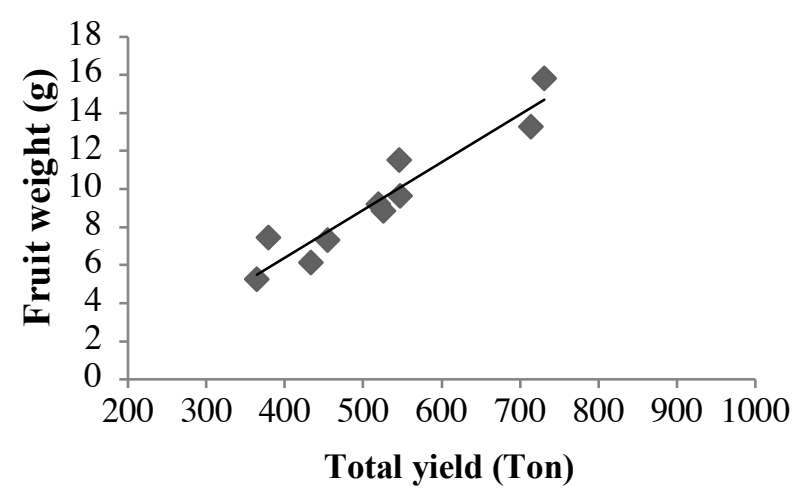

Regression of total yield on Fruit weight $\hat{\mathbf{Y}}=-\mathbf{3 . 6 4 7 + 0 . 0 2 5 X}, \mathrm{r}=\mathbf{0 . 9 5 2}, \mathrm{r}^{2}=\mathbf{0 . 9 0 6}, \mathrm{b}=\mathbf{0 . 0 2 5}$. Second season

Fig (1). Linear regression; correlation coefficients (r), coefficients of determination $\left(\mathrm{r}^{2}\right)$ and regression coefficients (b) of total yield (ton/feddan) on fruit weight, and regression of fruit weight on plant weight. 


\section{REFERENCES}

A.O.A.C. (1975). In: "Official Methods of Analysis of the Association of Official Analytical Chemists". Twelfth Ed. Published by the Association of Official Analytical chemists. Benjamin Frank line Station, Washington, DC.

A.O.A.C. (1990). In: "Official Methods of Analysis". Twelfth Ed. Published by the Association of Official Analytical Chemists. Benjamin Frank line station, Washington, DC.

Adeyeye, A.S., W.B. Akanbi, K.K. Olalekan, W.A. Lamidi, H.J. Othman and M.A. Ishaku (2017). The growth and yield performance of sweet melon as affected by planting spacing in North East Nigeria. Int. J. Res. Agric. Forestry, 4 (8): 17-21.

Alenazi, M., H. Abdel-Razzak, A. Ibrahim, M. Wahb-Allah and A. Alsadon (2015). Response of muskmelon cultivars to plastic mulch and irrigation regimes under greenhouse conditions. J. Anim. Plant Sci., 25 (5): 1398-1410.

Anwar, R.S. (2005). Response of potato crop to biofertilizers, irrigation and antitranspiration under sandy soil conditions. Ph.D. Thesis, Fac. Agric., Zagazig Univ., Egypt, 172 pp.

Ban, D., K. Žanić, G. Dumičić, T.G. Čuljak and S.G. Ban (2009). The type of polyethylene mulch impacts vegetative growth, yield, and aphid populations in watermelon production. J. Food Agric. Environ., 7 (3 \& 4): 543-550.

Brown, J.D. and O. Lilliland (1964). Rapid determination of potassium and sodium in plant material and soil extracts by flame photometer. Proc. Amer. Soc. Hort. Sci., 48: 341-346.

Cantore, V., B. Pace and R. Albrizio (2009). Kaolin-based particle film technology affects tomato physiology, yield and quality. Environ. Exp. Botany, 66: 279-288.

De Pascale, S., L.D. Costa, S. Vallone, G. Barbieri and A. Maggio (2011). Increasing water use efficiency in vegetable crop production: from plant to irrigation systems efficiency. HortTechnology, 21 (3): 301-308.

FAO STAT (2018). Available online: http://www.fao.org/faostat/ar/\#data.

Gordon, G.G., W.G. Foshee, S.T. Reed, J.E. Brown and E.L. Vinson (2010). The effects of colored plastic mulches and row covers on the growth and yield of okra. HortTechnology, 20 (1): 224-233.

Hochmuth, G.J., R.C. Hochmuth and S.M. Olson (2012). Polyethylene mulching for early vegetable production in North Florida. Florida Univ., IFAS Extension. Cir 805: 1-6.

Khurshid, K., M. Iqbal, M.S. Arif and A. Nawaz (2006). Effect of tillage and mulch on soil physical properties and growth of maize. Int. J. Agric. Biol., 5: 593-6.

Egyptian J. Desert Res., 70, No. 2, 121-136 (2020) 
Klute, A.J. (1986). Methods of soil analysis. No. (9), Part 1 - Physical and Mineralogical Methods. Am. Soc., Agron., Inc. Soil. Sci., Mad., Wisc., U.S.A.

Lamont, Jr.,W.J. (1996.) What are the components of a plasticulture vegetable system? HortTechnology, 6: 150-154.

Lamont, Jr.W.J. (2005). Plastics: Modifying the microclimate for the production of vegetable crops. HortTechnology, 15 (3): 477-481.

Loy, J.B. and O.S. Wells (1975). Response of hybrid muskmelons to polyethylene row covers and black polyethylene mulch. Sci. Hort., 3: 223-230.

Moursy, F.S., F.A. Mostafa and N.Y. Soliman (2015). Polyethylene and rice straw as soil mulching: reflection of soil mulch type on soil temperature, soil borne diseases, plant growth and yield of tomato. Global J. Adv. Res., 2 (10):1437-1519.

Pace, B., F. Boari, V. Cantore, L. Leo, S. Vanadia, E. De Palma and N. Phillips (2007). Effect of particle film technology on temperature, yield and quality of processing tomato. Acta Hortic., 758: 287293.

Page, A.L., R.H. Miller and D.R. Keeney (1982). In: "Methods of Soil Analysis". No. (9), Part 2. Chemical and Microbiological Properties. Am. Soc., Agron., Inc. Soil. Sci., Mad., Wisc., USA.

Prakash, M. and K. Ramachandran (2000). Effects of chemical ameliorants in brinjal (Solanum melongena L.) under moisture stress conditions. J. Agron. Crop Sci.,185: 237-239.

Thomas, M.L. and F.G. Hills (1975). In: "Statistical Methods In Agric. Research, California Univ., Davis $956162^{\text {nd }}$ printing, p. 67-74.

Wand, S.J.E., K.I. Theron and J. Ackerman (2006). Harvest and post-harvest apple fruit quality following applications of Kaolin particle film in South Africa orchards. Scientia Hort., 107: 271-276.

Wang, P., X. Sun, C. Li et al. (2013). Long-term exogenous application of melatonin delays drought-induced leaf senescence in apple. J. Pineal Res., 54: 292-302.

Wells, O.S. and J.B. Loy (1993). Row covers and high tunnels enhance crop production in the northeastern United States. HortTechnology, 3: 92-95

Yang, S.L., S.S. Lan and F.F. Deng (2016). Effects of calcium and calmodulin antagonists on chilling stress-induced proline accumulation in Jatropha curcas L. J. Plant Growth Regul., 35: 815-826.

Zhang, G., Y. Liu, Y. Ni et al. (2014). Exogenous calcium alleviates low night temperature stress on the photosynthetic apparatus of tomato leaves. PLoS One, 9: e97322. 


\section{تحسين إنتاجية الكنتالوب تحت ظروف درجات الحرارة المنفضة بواحة

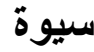

محمد عبد المعطي السجان

وحدة الخضر ، قسم الإنتاج النباتي، مركز بحوث الصدئ الصحر اء، المطرية، القاهرة، مصر

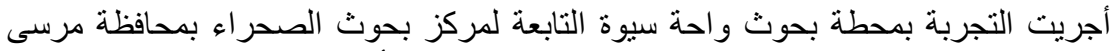

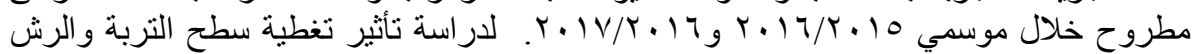

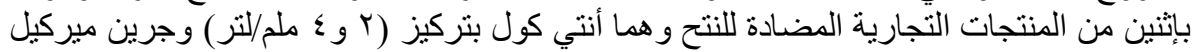

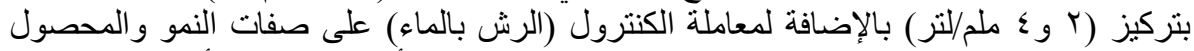

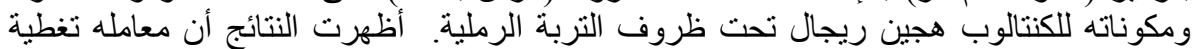

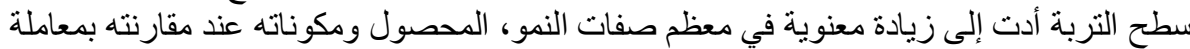

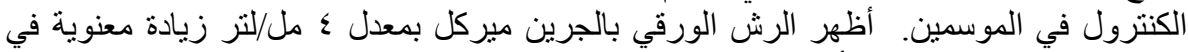

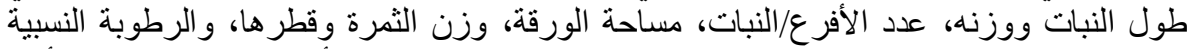

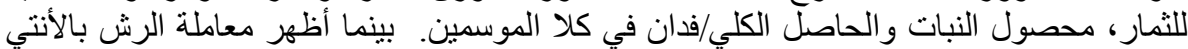

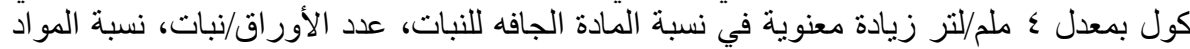

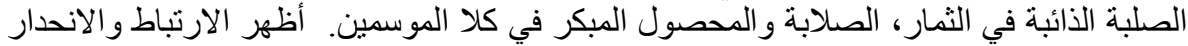

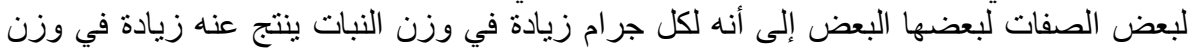

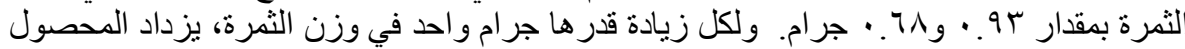

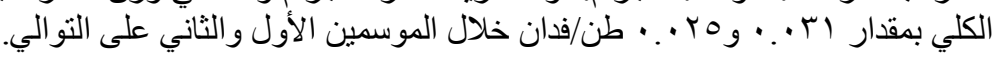

Egyptian J. Desert Res., 70, No. 2, 121-136 (2020) 